\title{
Combination of $\mathrm{Cu} / \mathrm{ZnO}$ Methanol Synthesis Catalysts and ZSM-5 Zeolites to Produce Oxygenates from $\mathrm{CO}_{2}$ and $\mathrm{H}_{2}$
}

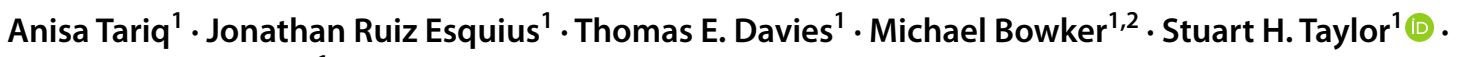 \\ Graham J. Hutchings ${ }^{1}$
}

Accepted: 7 May 2021 / Published online: 16 May 2021

(c) The Author(s) 2021

\begin{abstract}
$\mathrm{Cu} / \mathrm{ZnO}$ methanol catalysts were deposited over several ZSM-5 acid zeolites to directly synthesise oxygenates (methanol and dimethyl ether) from a $\mathrm{CO}_{2} / \mathrm{H}_{2}$ feed. Catalysts were prepared by two different preparation methodologies: chemical vapour impregnation (CZZ-CVI) and oxalate gel precipitation (CZZ-OG). Chemical vapour impregnation led to $\mathrm{Cu} / \mathrm{ZnO}$ being deposited on the zeolite surface, whilst oxalate gel precipitation led to the formation of $\mathrm{Cu} / \mathrm{ZnO}$ agglomerates. For both sets of catalysts a higher concentration of mild and strong acid sites were produced, compared to the parent ZSM-5 zeolites, and CZZ-CVI had a higher concentration of acid sites compared to CZZ-OG. Nevertheless, CZZ-OG shows considerably higher oxygenate productivity, $1322 \mathrm{mmol} \mathrm{Kg}_{\text {cat }}{ }^{-1} \mathrm{~h}^{-1}$, compared to $192 \mathrm{mmol} \mathrm{Kg}_{\text {cat }}{ }^{-1} \mathrm{~h}^{-1}$ over CZZ-CVI (ZSM-5(50), $250{ }^{\circ} \mathrm{C}, 20$ bar, $\mathrm{CO}_{2} / \mathrm{H}_{2}=1 / 3,30 \mathrm{ml} \mathrm{min}^{-1}$ ), which could be assigned to a combination of smaller particle size and enhanced methanol mass transfer within the zeolites.
\end{abstract}

Keywords $\mathrm{CO}_{2} \cdot \mathrm{Cu} \cdot \mathrm{ZnO} \cdot$ Dimethyl ether $\cdot$ Hydrogenation $\cdot$ Methanol $\cdot$ ZSM-5

\section{Introduction}

$\mathrm{CO}_{2}$ hydrogenation allows us to store hydrogen produced from renewable resources (green hydrogen) in the form of liquid fuels [1]. Thus, green hydrogen [2] can be readily incorporated into the current energy infrastructure, while prominent technologies (e.g. PEM electrolysers) which use hydrogen as an energy vector are well-established. Among the possible $\mathrm{CO}_{2}$ hydrogenation products [3], $\mathrm{CH}_{3} \mathrm{OH}$ is of great interest [4]. $\mathrm{CH}_{3} \mathrm{OH}$ can be blended with gasoline or converted into gasoline. For instance, in 1985 to meet the domestic fuel demand in New Zealand two methanol

Michael Bowker

BowkerM@cardiff.ac.uk

Stuart H. Taylor

TaylorSH@ cardiff.ac.uk

$\triangle$ Graham J. Hutchings

Hutch@cardiff.ac.uk

1 School of Chemistry, Cardiff Catalysis Institute, Cardiff University, Main Building, Park Place, Cardiff CF10 3AT, UK

2 Catalysis Hub, RCAH, Rutherford Appleton Laboratory, Harwell Oxford, Didcot OX11 0QX, UK plants were combined with the methanol-to-gasoline process developed by Mobil [5]. Moreover, $\mathrm{CH}_{3} \mathrm{OH}$ is also used as an intermediate for the production of numerous important chemicals (e.g. ethylene, propylene) [6] $\mathrm{CH}_{3} \mathrm{OH}$ is currently produced over $\mathrm{Cu} / \mathrm{ZnO} / \mathrm{Al}_{2} \mathrm{O}_{3}$ catalysts from syngas $\left(\mathrm{CO}+\mathrm{H}_{2}+\mathrm{CO}_{2}\right)$ at $200-300{ }^{\circ} \mathrm{C}$ and $80-120$ bar [5]. When $\mathrm{CO}_{2}$ (Eq. 1) is the feed instead of $\mathrm{CO}$ (Eq. 2) the $\mathrm{CH}_{3} \mathrm{OH}$ yield is constrained by equilibrium. For instance, at $250{ }^{\circ} \mathrm{C}$ and $30 \mathrm{bar}, \mathrm{CH}_{3} \mathrm{OH}$ yield is limited to $\mathrm{ca} .12 \mathrm{C}-\mathrm{mol} \%$, while $\mathrm{CH}_{3} \mathrm{OH}$ yield increase to $c a .42 \mathrm{C}$-mol \% using a $\mathrm{CO} /$ $\mathrm{CO}_{2}=4$ feed $\left(\mathrm{H}_{2} /\left(\mathrm{CO}+\mathrm{CO}_{2}\right)=3\right)$ [7]. Under laboratory testing conditions (20-50 bar) the $\mathrm{CO}_{2}$ hydrogenation to $\mathrm{CH}_{3} \mathrm{OH}$ is limited to the $200-270{ }^{\circ} \mathrm{C}$ range, at lower temperature little $\mathrm{CO}_{2}$ conversion is observed, while at higher $\mathrm{CH}_{3} \mathrm{OH}$ productivity is limited by equilibrium whilst the reverse water gas shift (RWGS) reaction is promoted (Eq. 3) [8].

$\mathrm{CO}_{2}+3 \mathrm{H}_{2} \rightleftharpoons \mathrm{CH}_{3} \mathrm{OH}+\mathrm{H}_{2} \mathrm{O} \quad \Delta \mathrm{H}^{\Theta}=-49.5 \mathrm{~kJ} \mathrm{~mol}^{-1}$

$\mathrm{CO}+2 \mathrm{H}_{2} \rightleftharpoons \mathrm{CH}_{3} \mathrm{OH} \quad \Delta \mathrm{H}^{\Theta}=-90.6 \mathrm{~kJ} \mathrm{~mol}^{-1}$

$\mathrm{CO}_{2}+\mathrm{H}_{2} \rightleftharpoons \mathrm{CO}+\mathrm{H}_{2} \mathrm{O} \quad \Delta \mathrm{H}^{\Theta}=41.2 \mathrm{~kJ} \mathrm{~mol}^{-1}$ 
$\mathrm{CH}_{3} \mathrm{OH}$ productivity from $\mathrm{CO}_{2}$ can be enhanced by simultaneously dehydrating $\mathrm{CH}_{3} \mathrm{OH}$ to dimethyl ether (DME) (Eq. 4) by combining a $\mathrm{CH}_{3} \mathrm{OH}$ synthesis catalyst with a solid acid catalyst (overall reaction in Eq. 5), known as hybrid catalysts. Like $\mathrm{CH}_{3} \mathrm{OH}$, DME synthesis from $\mathrm{CO}_{2}$ is favoured at low temperature and high pressure. DME synthesis from $\mathrm{CO}_{2}$ is advantageous compared to $\mathrm{CH}_{3} \mathrm{OH}$ because of the higher DME equilibrium selectivity. Moreover, DME can be employed as a fuel in diesel engines because of its higher cetane number and lower auto-ignition temperature compared to diesel fuel (55-60 compared to $40-50$, and $235^{\circ} \mathrm{C}$ compared to $250{ }^{\circ} \mathrm{C}$, respectively), and can be easily liquified at low pressure, hence it can be used as a liquified petroleum gas (LPG) substitute $[9,10]$.

$$
2 \mathrm{CH}_{3} \mathrm{OH} \rightleftharpoons\left(\mathrm{CH}_{3}\right)_{2} \mathrm{O}+\mathrm{H}_{2} \mathrm{O} \quad \Delta \mathrm{H}^{\Theta}=-24.0 \mathrm{~kJ} \mathrm{~mol}^{-1}
$$

$2 \mathrm{CO}_{2}+6 \mathrm{H}_{2} \rightleftharpoons\left(\mathrm{CH}_{3}\right)_{2} \mathrm{O}+3 \mathrm{H}_{2} \mathrm{O} \quad \Delta \mathrm{H}^{\Theta}=-123.0 \mathrm{~kJ} \mathrm{~mol}^{-1}$

Based on the actual $\mathrm{CH}_{3} \mathrm{OH}$ synthesis process (developed by Imperial Chemical Industries), most of the research on the $\mathrm{CO}_{2}$ hydrogenation to $\mathrm{CH}_{3} \mathrm{OH}$ focus on $\mathrm{Cu} / \mathrm{ZnO}$ catalysts [11]. As well summarised by Spencer [12], $\mathrm{ZnO}$ prevents the sintering of $\mathrm{Cu}$ particles by acting as a refractory spatial binder, maintaining small $\mathrm{Cu}$ crystallites from agglomerating during reaction [13]. Nevertheless, $\mathrm{ZnO}$ not only plays a spatial role in improving the catalyst lifespan, but it is also an activity promoter. As Spencer elucidated: on one hand, under $\mathrm{CH}_{3} \mathrm{OH}$ synthesis conditions surface $\mathrm{CuZn}$ alloys can form, leading to the formation of $\mathrm{Cu}^{+}-\mathrm{O}-\mathrm{Zn}$ active sites [14-16]. On the other hand, under laboratory testing conditions (moderate pressure, $\mathrm{CO}_{2} / \mathrm{H}_{2}=1 / 3$, high conversion) $\mathrm{H}_{2}$ dissociates on $\mathrm{ZnO}$ and spills over onto $\mathrm{Cu}$ particles [17]. For the $\mathrm{CH}_{3} \mathrm{OH}$ dehydration to dimethyl ether (DME) ZSM-5 zeolites are preferred to $y$-alumina as the acid catalyst because ZSM-5 zeolites contain Lewis and Brønsted acid sites, their high resistance to water, and their chemical and thermal stability [11]. For instance, Aguayo et al. [18] compared $\mathrm{Cu}-\mathrm{ZnO}-\mathrm{Al}_{2} \mathrm{O}_{3} / \mathrm{\gamma}-\mathrm{Al}_{2} \mathrm{O}_{3}$ and $\mathrm{Cu}-\mathrm{ZnO}-\mathrm{Al}_{2} \mathrm{O}_{3} /$ NaZSM-5 hybrid catalysts for $\mathrm{CH}_{3} \mathrm{OH}$ synthesis from the hydrogenation of $\mathrm{CO}$ and $\mathrm{CO}_{2}$. It was observed that competitive adsorption between $\mathrm{H}_{2} \mathrm{O}$ and $\mathrm{CH}_{3} \mathrm{OH}$ for acid sites on $\mathrm{\gamma}-\mathrm{Al}_{2} \mathrm{O}_{3}$, leading to lower $\mathrm{CO} / \mathrm{CO}_{2}$ conversion and $\mathrm{DME}$ selectivity compared to ZSM-5. Moreover, catalyst deactivation after regeneration was observed for the $\mathrm{\gamma}-\mathrm{Al}_{2} \mathrm{O}_{3}$ containing hybrid catalyst, whilst good regeneration was observed for the $\mathrm{Cu}-\mathrm{ZnO}-\mathrm{Al}_{2} \mathrm{O}_{3} / \mathrm{ZSM}-5$ hybrid catalyst. Similar conclusions were reported by Naik et al. [19] Bonura and co-workers studied the effect of water on $\mathrm{CH}_{3} \mathrm{OH}$ dehydration activity over ZSM-5 zeolites. At low temperature $\mathrm{H}_{2} \mathrm{O}$ competes with acid sites resulting in a decrease in $\mathrm{CH}_{3} \mathrm{OH}$ conversion, with higher deactivation observed with increasing the zeolite acidity. Whilst, no appreciable decrease in $\mathrm{CH}_{3} \mathrm{OH}$ dehydration was observed above $180{ }^{\circ} \mathrm{C}$ [20]. Readers are referred to reports by Catizzone et al. [21] and Álvarez et al. [11] for a detailed review on the $\mathrm{CO}_{2}$ upgrading to DME.

Frusteri et al. [20] compared the activity of $\mathrm{CuZnZr} /$ ZSM-5 hybrid catalysts with CuZnZr supported over ZSM-5 by co-precipitation. Catalysts where the $\mathrm{CH}_{3} \mathrm{OH}$ synthesis catalyst is supported over the solid acid catalyst are known as integrated catalysts. Slightly higher $\mathrm{CO}_{2}$ conversion and DME productivity was observed over the integrated catalyst, which was attributed to the spatial proximity between the two active functionalities. Due to the benefits of integrated catalysts over hybrid catalysts, the aim of this work is to compare DME productivity between CuZnO/ZSM-5 integrated catalysts prepared via chemical vapour impregnation (CVI) or via oxalate gel precipitation (OG).

\section{Experimental Section}

\subsection{Materials}

All materials employed in this work were purchased from chemical suppliers and used as received without prior purification. ZSM-5 zeolites in the $\left(\mathrm{NH}_{4}{ }^{+}\right)$form were purchased from Alfa Aesar $(\mathrm{Si} / \mathrm{Al}=23,50,80)$; $\mathrm{Zn}$ acetylacetonate $\left(\mathrm{Zn}(\mathrm{acac})_{2}, 99 \%\right), \mathrm{Cu}$ acetylacetonate $\left(\mathrm{Cu}(\mathrm{acac})_{2}, 97 \%\right)$, $\mathrm{Cu}$ nitrate hydrate $\left(\mathrm{Cu}\left(\mathrm{NO}_{3}\right)_{2} \cdot 3 \mathrm{H}_{2} \mathrm{O}, 99 \%\right)$ and $\mathrm{Zn}$ nitrate hydrate $\left(\mathrm{Zn}\left(\mathrm{NO}_{3}\right)_{2} \cdot 6 \mathrm{H}_{2} \mathrm{O}, 99 \%\right)$ and ethanol $(99.8 \%)$ were purchased from Sigma-Aldrich.

\subsection{Catalysts Synthesis}

CuZnO/ZSM-5 catalysts synthesised via Chemical Vapour Impregnation (CZZ-CVI). For the preparation of $3.0 \mathrm{~g}$ of CuZnO/ZSM-5 catalyst by CVI (20 wt. $\%, \mathrm{Cu} / \mathrm{Zn} \mathrm{mol}=1)$ $1.24 \mathrm{~g}$ of $\mathrm{Cu}(\mathrm{acac})_{2}, 1.21 \mathrm{~g} \mathrm{Zn}(\mathrm{acac})_{2}$ and $2.4 \mathrm{~g}$ of activated H-ZSM-5 (static air, $550{ }^{\circ} \mathrm{C}, 5{ }^{\circ} \mathrm{C} \mathrm{min}^{-1}, 4 \mathrm{~h}$ ) were thoroughly mixed in a glass vial. The homogeneous mixture was then transferred into a Schlenk flask, evacuated $\left(10^{-3} \mathrm{mbar}\right)$ and heated to $120{ }^{\circ} \mathrm{C}$ for $1 \mathrm{~h}$. Samples were then cooled to $30{ }^{\circ} \mathrm{C}$, recovered and annealed in static air $\left(500{ }^{\circ} \mathrm{C}, 2{ }^{\circ} \mathrm{C}\right.$ $\left.\min ^{-1}, 16 \mathrm{~h}\right)$.

CuZnO/ZSM-5 catalysts synthesised via Oxalate Gel precipitation (CZZ-OG). The procedure for the preparation of $3.0 \mathrm{~g}$ of $\mathrm{CuZnO} / \mathrm{ZSM}-5(20 \mathrm{wt} . \%, \mathrm{Cu} / \mathrm{Zn} \mathrm{mol}=1)$ catalysts by $\mathrm{OG}$ is as follows; $1.14 \mathrm{~g}$ of $\mathrm{Cu}\left(\mathrm{NO}_{3}\right)_{2}$ and $1.37 \mathrm{~g}$ of $\mathrm{Zn}\left(\mathrm{NO}_{3}\right)_{2}$ were dissolved in $200 \mathrm{ml}$ of ethanol, under vigorous stirring $2.4 \mathrm{~g}$ of activated H-ZSM-5 (static air, $550{ }^{\circ} \mathrm{C}$, $5{ }^{\circ} \mathrm{C} \mathrm{min}^{-1}, 4 \mathrm{~h}$ ) were added. $2.16 \mathrm{~g}$ of oxalic acid were added to the slurry. The precipitate was aged for $1 \mathrm{~h}$ under 
stirring, recovered by filtration, dried (static air, $100{ }^{\circ} \mathrm{C}, 16$ h) and annealed (static air, $500{ }^{\circ} \mathrm{C}, 10{ }^{\circ} \mathrm{C} \mathrm{min}^{-1}, 2 \mathrm{~h}$ ).

\subsection{Catalyst Characterisation}

Prior to characterisation a portion of the $\mathrm{CZZ}$ catalysts were reduced under flowing $5 \% \mathrm{H}_{2} / \mathrm{Ar}\left(220{ }^{\circ} \mathrm{C}, 2{ }^{\circ} \mathrm{C} \mathrm{min}{ }^{-1}, 1 \mathrm{~h}\right)$. Powder X-ray diffraction (XRD) patterns were recorded on a $(\theta-\theta)$ PANalyticalX'pert Pro powder diffractometer fitted with a position sensitive detector using a $\mathrm{Cu} \mathrm{K} \alpha$ radiation source $(40 \mathrm{keV}, 40 \mathrm{~mA})$. Transmission electron microscopy (TEM) images were obtained on a JEOL 2100 (LaB6) instrument fitted with a Gatan Ultrascan 1000xp digital camera operated at $200 \mathrm{kV}$. Specimens were dry-prepared on 300 mesh copper TEM-grids coated with holey carbon film. Pore size and apparent BET surface area were obtained from $\mathrm{N}_{2}$ adsorption isotherms at $\left(-196{ }^{\circ} \mathrm{C}\right)$ on a Quantachrome Nova $2200 \mathrm{e}$ instrument. Prior to analysis samples were degassed in situ $\left(120{ }^{\circ} \mathrm{C}, 10 \mathrm{~h}\right)$. Ammonia temperature programmed desorption ( $\mathrm{NH}_{3}$-TPD) were acquired on a Quantachrome ChemBET TPR/TPD equipped with a TCD detector. $150 \mathrm{mg}$ of pre-reduced catalyst were secured with quartz wool. Prior to analysis samples were heated under a He flow (130-140 $\left.\mathrm{ml} \mathrm{min}{ }^{-1}\right)$ at $400{ }^{\circ} \mathrm{C}\left(10^{\circ} \mathrm{C} \mathrm{min}{ }^{-1}, 1 \mathrm{~h}\right)$. The sample cell was cooled to $30{ }^{\circ} \mathrm{C}$, the flow was then switched to $10 \% \mathrm{NH}_{3} /$ Ar. After $15 \mathrm{~min}$ the gas was switched back to He, heated to $100{ }^{\circ} \mathrm{C}\left(10{ }^{\circ} \mathrm{C} \mathrm{min}-1,1 \mathrm{~h}\right)$ to remove physiosorbed $\mathrm{NH}_{3}$, and cooled to $50{ }^{\circ} \mathrm{C}$. $\mathrm{NH}_{3}$-TPD profiles were then measured $\left(50-700{ }^{\circ} \mathrm{C}, 10{ }^{\circ} \mathrm{C} \mathrm{min}^{-1}\right)$.

\subsection{Catalyst Performance for Oxygenates Synthesis from $\mathrm{CO}_{2}$ and $\mathrm{H}_{2}$}

The $\mathrm{CO}_{2}$ hydrogenation and consecutive $\mathrm{CH}_{3} \mathrm{OH}$ dehydration to DME was assessed in a stainless steel fixed-bed continuous flow reactor $(50 \mathrm{~cm}$ length, $0.5 \mathrm{~cm}$ internal diameter). Temperature was controlled through a chromel-alumel thermocouple placed inside the catalyst bed, pressure was controlled using a back pressure regulator. Catalysts were pressed (10 ton, $1 \mathrm{~min}$ ) into a $1.3 \mathrm{~cm}$ die, the die was then crushed, and sieved into $(425-600 \mu \mathrm{m})$ pellets. $0.5 \mathrm{~g}$ of catalyst pellets were placed in the reactor tube without diluent, quartz wool was used to secure the catalyst bed in place. Prior to reaction catalysts were pre-reduced in situ with $5 \% \mathrm{H}_{2} / \mathrm{Ar}\left(1 \mathrm{bar}, 30 \mathrm{ml} \mathrm{min}{ }^{-1}, 220{ }^{\circ} \mathrm{C}, 2{ }^{\circ} \mathrm{C} \min ^{-1}, 1 \mathrm{~h}\right)$. After pre-reduction, the reactor was cooled down to $50{ }^{\circ} \mathrm{C}$, the gas flow was switched to the reaction mixture $\left(\mathrm{CO}_{2} /\right.$ $\mathrm{H}_{2} / \mathrm{N}_{2}=1 / 3 / 1$ ), the reactor was pressurised to 20 bar and heated to the desired reaction temperature $\left(230-310{ }^{\circ} \mathrm{C}\right)$. Post-reactor lines and valves were heated at $130{ }^{\circ} \mathrm{C}$ to avoid product condensation. Catalytic activity was simultaneously compared against a blank reactor tube under the same reaction conditions. Products were analysed via online GC analysis (Agilent 7890, fitted with FID and TCD detectors).

\section{Results and Discussion}

\subsection{Catalyst Characterisation}

CuZnO/ZSM-5 integrated catalysts (20 wt.\% $\mathrm{Cu}$ and $\mathrm{Zn}$, $\mathrm{Cu} / \mathrm{Zn} \mathrm{mol}=1)$ were prepared via oxalate gel precipitation (OG) and chemical vapour impregnation (CVI) over commercially sourced ZSM-5 zeolites ( $\mathrm{Si} / \mathrm{Al}=80,50$ and 23 ). Precipitation of $\mathrm{Cu}$ and $\mathrm{Zn}$ nitrate precursors in the presence of carbonates or hydroxides is commonly reported for the preparation of $\mathrm{CH}_{3} \mathrm{OH}$ synthesis catalysts [11], however, physicochemical properties strongly depend on preparation parameters such as $\mathrm{pH}$, temperature, precipitation rate, ageing and drying [22-24]. Instead, the oxalate gel precipitation method is reported to yield small, well dispersed nanoparticles with high $\mathrm{Cu}$ surface area and homogeneous $\mathrm{Cu} / \mathrm{Zn}$ distribution $[25,26]$. This method was employed to prepare CuZnO/ZSM-5 integrated catalysts (CZZ-OG). CVI was also used for the preparation of CuZnO/ZSM-5 integrated catalysts (CZZ-CVI), because it allows the preparation of well dispersed bimetallic catalysts, and can be used over a wide range of supports, avoids the use of chloride metal precursors and avoids the presence of possible impurities from the use of solvents, ligands and reducing/precipitating agents [27-30]. Catalyst characterisation was performed on a portion of the pre-reduced sample $\left(5 \% \mathrm{H}_{2} / \mathrm{Ar}, 220{ }^{\circ} \mathrm{C}\right.$, $2{ }^{\circ} \mathrm{C} \min ^{-1}, 1 \mathrm{~h}$ ).

The porous structure of commercial ZSM- $5(\mathrm{Si} / \mathrm{Al}=23$, 50 and 80 ) zeolites after activation (static air, $550{ }^{\circ} \mathrm{C}$, $5{ }^{\circ} \mathrm{C} \min ^{-1}, 4 \mathrm{~h}$ ) was determined by $\mathrm{N}_{2}$ adsorption. Due to the limitations of using $\mathrm{N}_{2}$ as adsorbent for the analysis of porous materials (microporous filling due to strong adsorption at low $\mathrm{p} / p^{0}$, non-uniform monolayer structure leading to different molecular $\mathrm{N}_{2}$ areas) [31] and that commercially supplied zeolites were employed, values reported in this work were used to qualitatively compare materials. Comparable pore size (ca.5.5 $\mathrm{\AA}$ ) and apparent BET surface area $\left(c a .460 \mathrm{~m}^{2} \mathrm{~g}^{-1}\right)$ were measured for all three zeolites (Table S1). A slight decrease in the pore size was observed for CZZ-OG and CZZ-CVI catalysts, nevertheless, the BET surface area of the integrated catalysts was significantly lower than the parent zeolites (Table 1). Suggesting that $\mathrm{Cu} /$ $\mathrm{ZnO}$ nanoparticles were mainly at the surface and not within the zeolite pore structure. BET values are representative of the average surface area of the catalyst, for CZZ catalysts reported in this work, ZSM-5 zeolites were loaded with a $c a .9 .7$ wt.\% $\mathrm{Cu}$ and $c a .10 .3 \mathrm{wt} . \% \mathrm{Zn}$. Hence, a decrease in the surface area is expected, and not indicative of the metal distribution within the pore structure. 
Table 1 Pore size and apparent BET surface area for CZZ-OG and CZZ-CVI integrated catalysts measured by means of $\mathrm{N}_{2}$ adsorption

\begin{tabular}{lll}
\hline Catalyst & Pore size/A & $\mathrm{BET} / \mathrm{m}^{2} \mathrm{~g}^{-1}$ \\
\hline CZZ(80)-OG & 5.0 & 303 \\
CZZ(50)-OG & 5.0 & 211 \\
CZZ(23)-OG & 4.9 & 277 \\
CZZ(80)-CVI & 4.8 & 297 \\
CZZ(50)-CVI & 4.9 & 273 \\
CZZ(23)-CVI & 4.8 & 258 \\
\hline
\end{tabular}

X-ray powder diffraction (XRD) was employed to determine the crystalline phases present in integrated catalysts after pre-reduction. For comparison, XRD patterns for CZZ(23)-OG, CZZ(23)-CVI and ZSM-5(23) are shown in Fig. 1 (XRD patterns for all integrated catalysts and activated ZSM-5 zeolites can be found in Figure S1 and Figure $\mathrm{S} 2$, respectively). The presence of metallic $\mathrm{Cu}$ (PDF 01-0703038) was observed at $43.2^{\circ}, 50.3^{\circ}$ and $73.9^{\circ}$. Reflections not assigned to ZSM-5(23) (MFI morphology PDF 00-891421 ) or to $\mathrm{Cu}$ were attributed to the presence of $\mathrm{ZnO}$ (PDF 00-036-1451). Sharper $\mathrm{Cu}$ and $\mathrm{ZnO}$ peaks were observed for integrated catalysts prepared by CVI, compared to catalysts prepared by OG, indicating that the former methodology yielded larger crystallites. Oxalate gel co-precipitation has been reported to yield small and well distributed $\mathrm{Cu} / \mathrm{ZnO}$ $[25,26]$, however, differences in the crystallite size between CVI and OG could be also attributed to the difference in annealing treatment. The former was annealed at $500{ }^{\circ} \mathrm{C}$ for $16 \mathrm{~h}$ to ensure the complete decomposition of the acetylacetonate precursors, whilst for the latter the annealing at

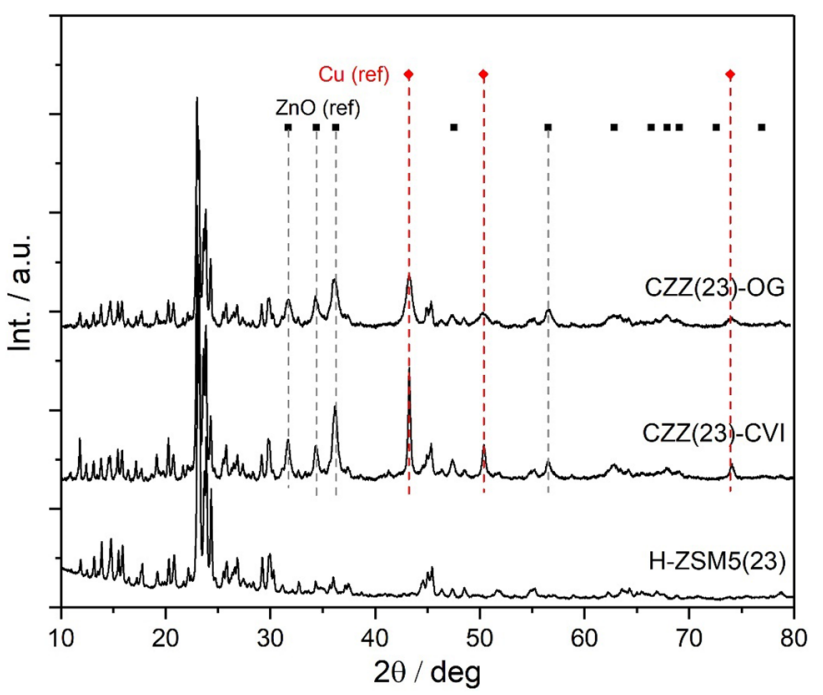

Fig. 1 XRD patterns for H-ZSM-5(23), CZZ(23)-OG and CZZ(23)CVI after reduction $\left(5 \% \mathrm{H}_{2} / \mathrm{Ar}, 220{ }^{\circ} \mathrm{C}, 2{ }^{\circ} \mathrm{C} \mathrm{min}^{-1}, 1 \mathrm{~h}\right)$
$500{ }^{\circ} \mathrm{C}$ was limited to $2 \mathrm{~h}$ to avoid unnecessary crystallite growth. $\mathrm{No}_{2} \mathrm{Cu}_{2} \mathrm{O}$ (PDF 01-071-3645) or $\mathrm{CuO}$ (PDF 00-0481548 ) peaks at $36.4^{\circ}$ or $35.6^{\circ}$ were observed. The $\mathrm{Cu}$ and $\mathrm{ZnO}$ crystallite size for CZZ-OG and CZZ-CVI catalysts was estimated using the Scherrer equation (Table 2). Details on how the Scherrer equation was applied to measure $\mathrm{Cu}$ and $\mathrm{ZnO}$ crystallite sizes can be found in the supporting information (Equation S1-S2). In accordance with $\mathrm{N}_{2}$ adsorption measurements, no significant changes in the pore size were observed between parent zeolites and integrated catalysts, and the measured $\mathrm{Cu}$ and $\mathrm{ZnO}$ crystallite sizes were considerably larger than the zeolite pores. Hence $\mathrm{Cu}$ and $\mathrm{ZnO}$ crystallites are physically unable to fit inside the zeolite pores. It was also observed that the oxalate gel precipitation yielded five-fold smaller $\mathrm{Cu}$ crystallites compared to CVI.

Morphological differences between CZZ(23)-OG and CZZ(23)-CVI integrated catalysts were analysed by TEM. Figure S3a and Figure S3b show low magnification TEM images for CZZ(23)-OG, it can be observed that most of the $\mathrm{Cu}$ and $\mathrm{ZnO}$ is not supported at the surface of the ZSM5(23) zeolite, but instead forms large phase separated aggregates $(\mathrm{nm}-\mu \mathrm{m})$. These large aggregates contradict the $\mathrm{Cu}$ crystallite size determined by XRD through the Scherrer equation. However, as shown in Fig. 2a, the large aggregates are made of smaller nanoparticles, in the size range determined by XRD ( $c a .15 \mathrm{~nm}$ as shown in Fig. 2b).

For CZZ(23)-CVI catalyst two distinct cases are observed. The $\mathrm{Cu} / \mathrm{ZnO}$ nanoparticles are not well dispersed over every zeolite particle. Zeolite particles either display a complete absence of $\mathrm{Cu} / \mathrm{ZnO}$ particles (Fig. 3a) or are covered with small and well-dispersed $\mathrm{Cu} / \mathrm{ZnO}$ nanoparticles (Fig. 3b). Prolonged exposure of the "particle free" zeolite areas under the electron beam led to the formation of $\mathrm{Cu}$ / $\mathrm{ZnO}$ aggregates on the zeolite surface (Figure $\mathrm{S} 4 \mathrm{a}$ to $\mathrm{S} 4 \mathrm{c}$ ). This behaviour was not observed for the CZZ-OG sample, furthermore, the zeolite showed no morphological change under the same beam conditions. This suggests that the $\mathrm{Cu} /$ $\mathrm{ZnO}$ is deposited as a film over the surface or as sub-nm particles or clusters inside the zeolite porous framework which are beyond the resolution of the microscope used, and were

Table $2 \mathrm{Cu}$ and $\mathrm{ZnO}$ crystallite sizes for CZZ-OG and CZZ-CVI catalysts obtained from the Scherrer equation

\begin{tabular}{lll}
\hline Catalyst & Cu crystallite size/nm & $\begin{array}{l}\text { ZnO crys- } \\
\text { tallite size/ } \\
\mathrm{nm}\end{array}$ \\
\hline CZZ(80)-OG & 15 & 14 \\
CZZ(50)-OG & 13 & 15 \\
CZZ(23)-OG & 13 & 12 \\
CZZ(80)-CVI & 76 & 21 \\
CZZ(50)-CVI & 54 & 22 \\
CZZ(23)-CVI & 51 & 38 \\
\hline
\end{tabular}


Fig. 2 TEM imaged for CZZ(23)-OG showing (a) large aggregates of $\mathrm{Cu}$ and $\mathrm{ZnO}$ made of smaller nanoparticles and (b) size of the $\mathrm{Cu}$ and $\mathrm{ZnO}$ nanoparticles
Fig. 3 TEM images for CZZ(23)-CVI showing (a) large areas of support which appears to be metal free and (b) small and evenly distributed $\mathrm{Cu}$ and $\mathrm{ZnO}$ nanoparticles
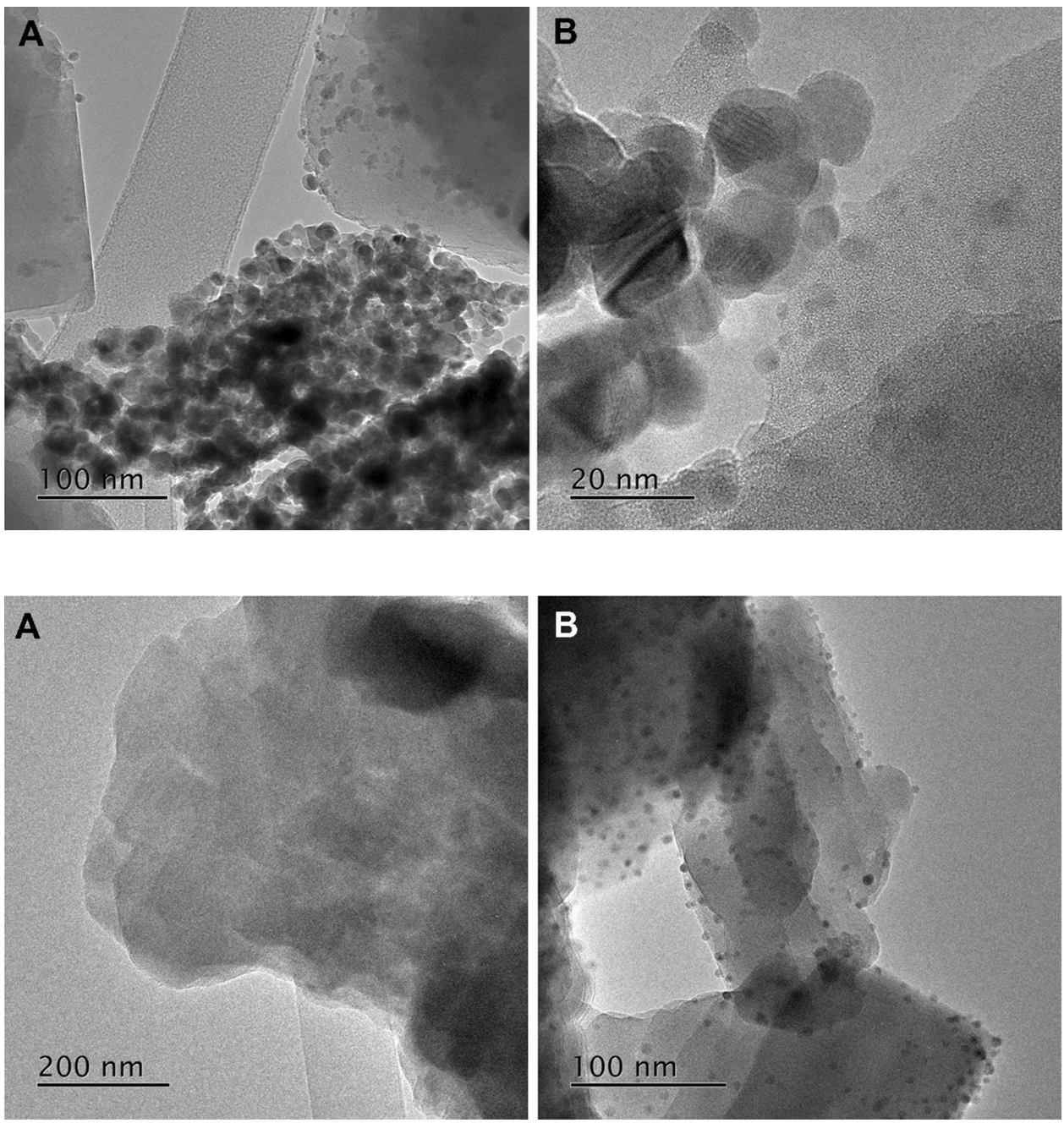

formed by beam induced sintering, which could be related to the large $\mathrm{Cu}$ and $\mathrm{ZnO}$ crystallite sizes observed by XRD analysis.

The $\mathrm{CH}_{3} \mathrm{OH}$ dehydration to DME is an acid catalysed reaction. Because of the presence of Brønsted and Lewis acid sites zeolites are less prone to deactivation than $\mathrm{Al}_{2} \mathrm{O}_{3}$ during $\mathrm{CH}_{3} \mathrm{OH}$ dehydration. This is explained by the higher affinity of Brønsted acid sites towards $\mathrm{CH}_{3} \mathrm{OH}$ compared to water [32]. The acidity of zeolites is an important parameter to optimise $\mathrm{CH}_{3} \mathrm{OH}$ dehydration. Increasing the $\mathrm{Al}$ concentration within the structure strengthens the acidity, this leads to improved $\mathrm{CH}_{3} \mathrm{OH}$ conversion, but usually at the expense of DME selectivity towards the production of other hydrocarbons, and decreases catalyst lifetime due to coke deposition [33]. $\mathrm{NH}_{3}$ is normally employed to characterise the acid properties of porous materials because of its strong basicity and small molecular size. Ammonia temperature programmed desorption ( $\mathrm{NH}_{3}$-TPD) was employed to compare acid properties of activated zeolites and $\mathrm{Cu}-\mathrm{ZnO}$ integrated catalysts. It is worth remembering that $\mathrm{NH}_{3}$-TPD interpretation is challenging because it depends on experimental conditions (e.g. amount of sample, pre-treatment) and several desorption phenomena (e.g. $\mathrm{NH}_{3}$ diffusion within pore structure and re-adsorption) [34, 35]. Often peak deconvolution models are needed to fully interpret $\mathrm{NH}_{3}$-TPD profiles. To add to the $\mathrm{NH}_{3}$-TPD interpretation complexity, one must consider that ZSM-5 zeolites can have 96 different Brønsted acid sites (oxygen bridging a $\mathrm{Si}$ and a $\mathrm{Al}$ atoms in the framework, although two positions are predominantly stable) $[36,37]$, which would need to be included into the $\mathrm{NH}_{3}$-TPD peak model. Hence, $\mathrm{NH}_{3}$-TPD measurements in this work are discussed in a qualitative manner. Figure S5 shows $\mathrm{NH}_{3}$-TPD profiles for activated ZSM-5 zeolites. Two distinct peaks were observed; a first desorption peak between 230 and $260{ }^{\circ} \mathrm{C}$ associated with weakly bonded $\mathrm{NH}_{3}$, likely to correspond to Lewis acid sites, and a second peak between 440 and $500{ }^{\circ} \mathrm{C}$ associated with more strongly bound $\mathrm{NH}_{3}$, likely related to Brønsted acid sites [38]. Although, as observed by the clear shoulder on the first desorption peak for ZSM-5(50), this first peak is made of several desorption contributions. As expected, higher Al content in the zeolite resulted in a higher concentration of acid (higher peak area) 
sites and stronger acidity (peak shift towards higher temperature) [20]. $\mathrm{NH}_{3}$-TPD profiles for CZZ-CVI and CZZ-OG integrated catalysts are shown in Fig. 4a and Fig. 4b, respectively. The $\mathrm{NH}_{3}$-TPD for integrated catalyst shows that the acid sites of parent zeolites have significantly changed after the addition of $\mathrm{Cu}$ and $\mathrm{ZnO}$. Instead of the two distinct peaks observed for ZSM-5 indicating the presence of Lewis and Brønsted acid sites, the integrated catalysts showed multiple $\mathrm{NH}_{3}$ desorption processes with an extra feature associated with medium acidity $\left(300-380^{\circ} \mathrm{C}\right)$. Moreover, the concentration of strong acid sites increased for synthesised integrated catalysts compared to parent zeolites, as also reported for other CuZnO-zeolite hybrid systems [38, 39]. The acid properties between CZZ(50 and 80)-CVI and CZZ(50 and 80)-OG are fairly comparable. However, a considerably higher concentration of strong acid sites was detected for CZZ(23)-CVI compared to CZZ(23)-OG.

\subsection{Catalyst Performance for DME Production}

Synthesised CZZ integrated catalysts are bifunctional catalysts, containing $\mathrm{Cu}$-active sites for the $\mathrm{CO}_{2}$ hydrogenation to $\mathrm{CH}_{3} \mathrm{OH}$ and acid sites within the zeolite for the consecutive dehydration of $\mathrm{CH}_{3} \mathrm{OH}$ to DME. The catalytic $\mathrm{CO}_{2}$ hydrogenation $\left(\mathrm{CO}_{2} / \mathrm{H}_{2} / \mathrm{N}_{2}=1 / 3 / 1,30 \mathrm{ml} \mathrm{min}^{-1}\right)$ to oxygenates $\left(\mathrm{CH}_{3} \mathrm{OH}\right.$ and DME) was assessed at $230-310{ }^{\circ} \mathrm{C}$ and 20 bar. Prior to reaction catalysts were pre-reduced in situ with $5 \% \mathrm{H}_{2} / \mathrm{Ar}\left(5 \% \mathrm{H}_{2} / \mathrm{Ar}, 220^{\circ} \mathrm{C}, 2{ }^{\circ} \mathrm{C} \mathrm{min}{ }^{-1}, 1 \mathrm{~h}\right)$. Details on how $\mathrm{CO}_{2}$ conversion, product selectivity and productivities can be found in the supporting information (Equation S3-S11).

The catalytic trend expected for the $\mathrm{CO}_{2}$ hydrogenation to $\mathrm{CH}_{3} \mathrm{OH}$ with temperature was observed on all synthesised catalysts (Table S2). Increasing the reaction temperature from 230 to $310{ }^{\circ} \mathrm{C}$ facilitates $\mathrm{CO}_{2}$ activation, which translates into higher $\mathrm{CO}_{2}$ conversion. However, as dictated by thermodynamics, higher temperature favour the endothermic RGWS instead of the exothermic $\mathrm{CH}_{3} \mathrm{OH}$ (and DME) synthesis, as observed by the increase in $\mathrm{CO}$ selectivity and productivity with temperature [7]. For instance, at 20 bar $\left(\mathrm{CO}_{2} / \mathrm{H}_{2}=1 / 3\right)$ the theoretical $\mathrm{CH}_{3} \mathrm{OH}$ yield decreases from $10.89\left(\mathrm{C} \mathrm{mol} \mathrm{\% )}\right.$ ) at $230{ }^{\circ} \mathrm{C}$ to $1.45(\mathrm{C} \mathrm{mol} \mathrm{\%})$ at $300{ }^{\circ} \mathrm{C}$, whilst the $\mathrm{CO}$ yield increases from 9.10 to 23.02 (C mol \%). When $\mathrm{CH}_{3} \mathrm{OH}$ is simultaneously dehydrated a DME yield of $20.26(\mathrm{C} \mathrm{mol} \mathrm{\%})$ can be achieved at $230{ }^{\circ} \mathrm{C}$, but it is limited to $1.39\left(\mathrm{C} \mathrm{mol} \mathrm{\% )}\right.$ ) at $300{ }^{\circ} \mathrm{C}$ [7].

CZZ-CVI catalysts showed poor $\mathrm{CO}_{2}$ conversion ( $c$ a. $3 \%$ at $250{ }^{\circ} \mathrm{C}$ ) compared to CZZ-OG (c.a. $14-20 \%$ at $250{ }^{\circ} \mathrm{C}$ ). This could indicate that mass transfer of $\mathrm{CO}_{2}$ is limited over CZZ-CVI, which could be attributed to $\mathrm{Cu} / \mathrm{ZnO}$ blocking the surface of zeolite particles as suggested by TEM. Whilst CZZ-OG catalysts were formed by $\mathrm{Cu} / \mathrm{ZnO}$ agglomerates not deposited on the zeolite surface, which resulted in an unobstructed zeolite porous structure. Moreover, no hydrocarbons (HC) were observed over CZZ-CVI catalysts, even at $310{ }^{\circ} \mathrm{C}$. The absence of $\mathrm{HC}$ on CZZ-CVI catalysts suggested that either $\mathrm{CH}_{3} \mathrm{OH}$ cannot diffuse into the ZSM-5 acid sites or that $\mathrm{HC}$ formed cannot diffuse out of the zeolite pores. Both scenarios suggest that $\mathrm{Cu} / \mathrm{ZnO}$ might be
Fig. $4 \mathrm{NH}_{3}$-TPD profiles for (a) CZZ-CVI and (b) CZZ-OG integrated catalysts over commercial ZSM-5 zeolites with different $\mathrm{Si} / \mathrm{Al}$ ratios
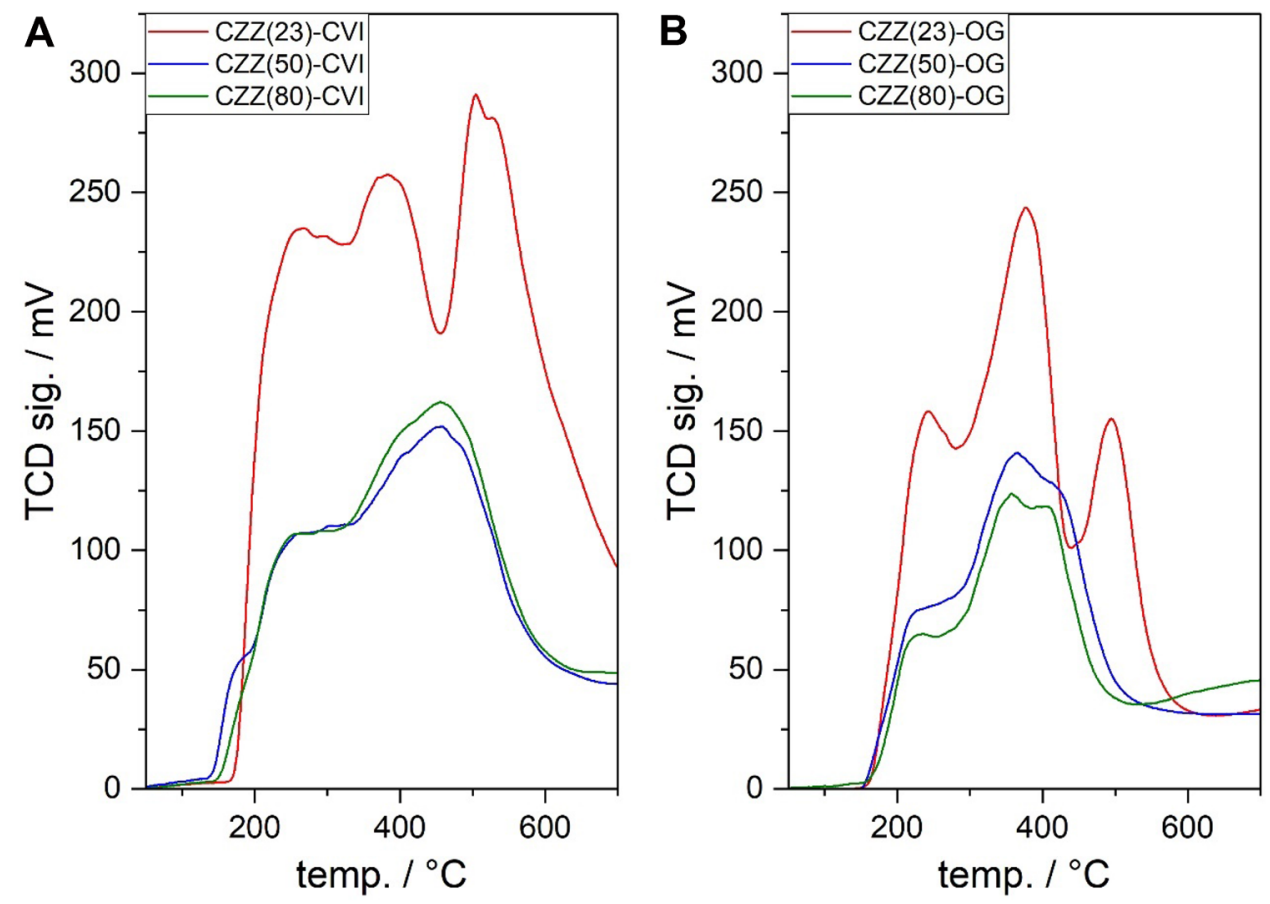


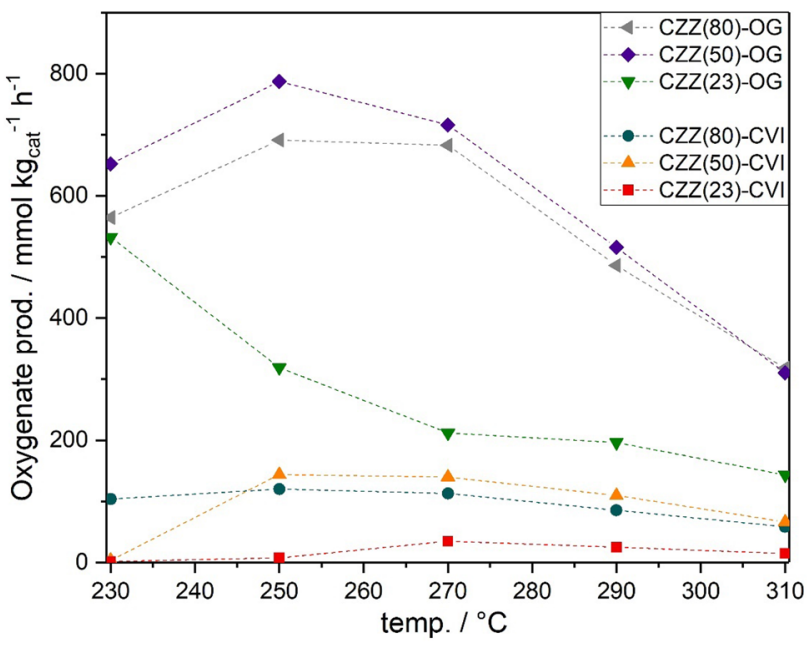

Fig. 5 Oxygenate $\left(\mathrm{CH}_{3} \mathrm{OH}+\mathrm{DME}\right)$ productivity obtained over CZZOG and CZZ-CVI catalysts (20 bar, $\mathrm{CO}_{2} / \mathrm{H}_{2} / \mathrm{N}_{2}=1 / 3 / 1,30 \mathrm{ml} \mathrm{min}{ }^{-1}$ )

blocking the entrance of ZSM-5 channels. The selectivity towards oxygenates over CZZ-OG catalysts is higher than over CZZ-CVI, higher selectivity in addition to higher $\mathrm{CO}_{2}$ conversion translated in almost a six-fold higher oxygenate productivity over CZZ-OG compared to CZZ-CVI at $230{ }^{\circ} \mathrm{C}$ (Fig. 5). As expected from thermodynamics, the higher oxygenate productivity was observed at lower temperature, while increasing the reaction temperature above $250{ }^{\circ} \mathrm{C}$ resulted in a decrease in oxygenate productivity over $\mathrm{CZZ}$ (80 and 50)-OG catalysts. This can be assigned to equilibrium limitations at high temperature, for both $\mathrm{CH}_{3} \mathrm{OH}$ and DME synthesis from $\mathrm{CO}_{2}$ hydrogenation [7], as well as to the more favoured side reactions, leading to the formation of hydrocarbons [32]. Increasing the $\mathrm{Si} / \mathrm{Al}$ ratio from 50 to 80 favoured $\mathrm{CH}_{3} \mathrm{OH}$ dehydration to DME, leading to higher oxygenates productivity. However, further increasing the $\mathrm{Si} /$ $\mathrm{Al}$ ratio, as in CZZ(23)-OG, resulted in the conversion of oxygenates to undesired by-products.

The formation of undesired hydrocarbons is to be avoided not only because it decreases the selectivity towards oxygenates and complicates the separation process, but also because it is normally associated with zeolites deactivation through coke formation [40]. ZSM-5 zeolites are widely used for the synthesis of $\mathrm{HC}$ from $\mathrm{CH}_{3} \mathrm{OH}$ and DME [41-43], in the so called methanol-to-hydrocarbons process (MTH) [44]. On MTH, methanol absorbs on Brønsted acid sites yielding surface methoxy species, methoxy species recombine forming $\mathrm{C}-\mathrm{C}$ bonds (carbene species) with increasing reaction temperature [45]. Carbene species promote the autocatalytic formation of hydrocarbons via the dual-cycle mechanism [46-48]. The Si/Al ratio determines the concentration of acid sites on zeolites, increasing the $\mathrm{Al}$ concentration results in a higher concentration of Brønsted acid sites, increasing the chance of forming active carbene species leading to greater hydrocarbon formation [49]. The effect of increasing the $\mathrm{Al}$ content on CZZ-OG catalysts on the productivity of hydrocarbons is shown in Fig. 6. No HC were detected over CZZ(80)-OG and CZZ(50)-OG below 270 and $250{ }^{\circ} \mathrm{C}$, respectively. HC selectivity remained low $(<0.03 \%)$ for CZZ(50 and 80)-OG catalysts at $290{ }^{\circ} \mathrm{C}$, with ethane being the only by-product detected. Nevertheless, a selectivity of c.a. $0.5 \%$ towards $\mathrm{HC}$ was observed over CZZ(23)-OG, even at $230{ }^{\circ} \mathrm{C}$. Increasing the reaction temperature from 230 to $270{ }^{\circ} \mathrm{C}$ resulted in an increase in the $\mathrm{HC}$ selectivity to $3.4 \%$. As shown in Fig. 5, oxygenate productivity for CZZ(23)OG does not increase with temperature up to $250{ }^{\circ} \mathrm{C}$, as observed for $\mathrm{CZZ(50} \mathrm{and} \mathrm{80)-OG,} \mathrm{but} \mathrm{instead} \mathrm{decreases}$ steadily with temperature, indicating the conversion of oxygenates to undesired by-products. Over CZZ(23)-OG a range of by-products up to $\mathrm{C}_{5}$ hydrocarbons were detected. Further increasing the reaction temperature to $310^{\circ} \mathrm{C}$ resulted in a drop in $\mathrm{HC}$ productivity (Table $\mathrm{S} 2$ ), which likely relates to low $\mathrm{CH}_{3} \mathrm{OH}$ availability.

\section{Conclusions}

The preparation methodology of integrated catalysts has a great influence on the $\mathrm{Cu} / \mathrm{ZnO}$ crystallite size and their distribution over ZSM-5 particles. Thus, influencing the $\mathrm{CO}_{2}$ hydrogenation activity towards $\mathrm{CH}_{3} \mathrm{OH}$ and the concomitant dehydration to DME.

$\mathrm{CVI}$ preparation leads to bigger $\mathrm{Cu}$ and $\mathrm{ZnO}$ nanoparticles, and an uneven distribution on CZZ-CVI catalysts: small nanoparticles evenly distributed over the surface of ZSM-5 were observed, whilst what appeared to be ZSM-5 areas free of metal showed particle agglomeration under

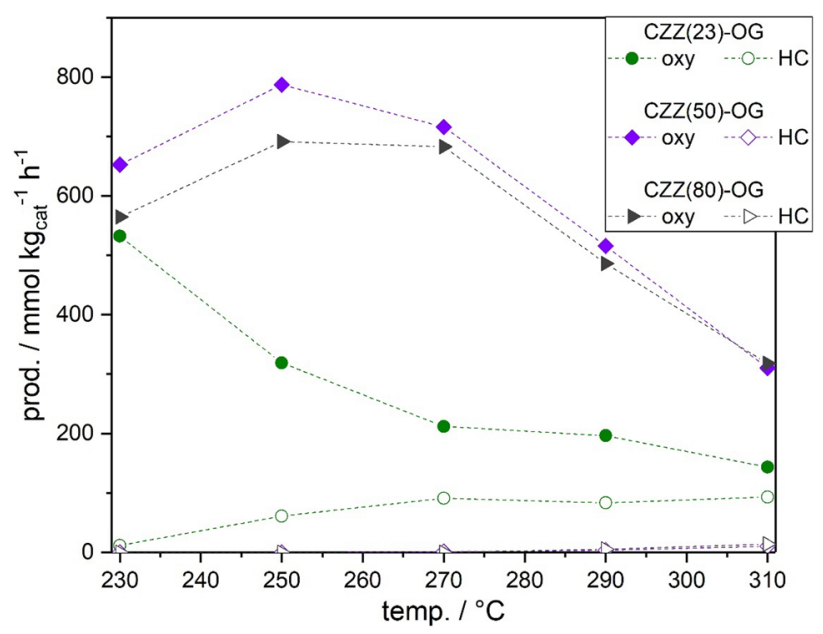

Fig. 6 Oxygenates and hydrocarbons productivity for CZZ-OG integrated catalysts as a function of temperature $\left(20\right.$ bar, $\mathrm{CO}_{2} / \mathrm{H}_{2} /$ $\mathrm{N}_{2}=1 / 3 / 1,30 \mathrm{ml} \mathrm{min}^{-1}$ ) 
the TEM electron beam. Suggesting that $\mathrm{Cu}$ and $\mathrm{ZnO}$ were deposited in the outermost zeolite pores or as a film at the surface, leading to poor $\mathrm{CO}_{2}$ conversion and to possibly mass transfer limitations. In this case, possibly a better route to avoid mass transfer limitations would be to prepare $\mathrm{Cu}$ / $\mathrm{ZnO}$ methanol catalysts by CVI and physically mixed them with ZSM-5 zeolites.

OG resulted in $\mathrm{Cu} / \mathrm{ZnO}$ agglomerates, made of smaller $20 \mathrm{~nm}$ aggregates, that did not obstruct the zeolite pores. Which resulted in higher $\mathrm{CO}_{2}$ conversion and oxygenates productivity compared to CZZ-CVI catalysts. The presence of acid sites is necessary to dehydrate $\mathrm{CH}_{3} \mathrm{OH}$ to DME. However, a compromise between acid sites concentration is required to avoid excessive formation of hydrocarbons. The high concentration of acid sites on CZZ(23)-OG led to the conversion of oxygenates to $\mathrm{HC}$, whilst no $\mathrm{HC}$ were detected for $\mathrm{CZZ}(50$ and 80$)-\mathrm{OG}$ below $250^{\circ} \mathrm{C}$, the temperature with the higher oxygenates productivity ( $c a .800 \mathrm{mmol} \mathrm{kg}_{\mathrm{cat}}{ }^{-1} \mathrm{~h}^{-1}$ over CZZ(50)-OG).

Supplementary Information The online version contains supplementary material available at https://doi.org/10.1007/s11244-021-01447-8.

Acknowledgements The authors acknowledge the EPSRC (EP/ N010531/1) and the UK Catalysis Hub for funding. Information on the data underpinning the results presented here can be obtained from the Cardiff University data catalogue on request (DOI:10.170 35/d.2021.0129557921). This manuscript is dedicated to Michael S. Spencer and in memory of his pioneering work on $\mathrm{CH}_{3} \mathrm{OH}$ synthesis over $\mathrm{Cu} / \mathrm{ZnO}$ catalysts.

\section{Declarations}

Conflict of Interest The authors declare that they have no conflict of interest.

Open Access This article is licensed under a Creative Commons Attribution 4.0 International License, which permits use, sharing, adaptation, distribution and reproduction in any medium or format, as long as you give appropriate credit to the original author(s) and the source, provide a link to the Creative Commons licence, and indicate if changes were made. The images or other third party material in this article are included in the article's Creative Commons licence, unless indicated otherwise in a credit line to the material. If material is not included in the article's Creative Commons licence and your intended use is not permitted by statutory regulation or exceeds the permitted use, you will need to obtain permission directly from the copyright holder. To view a copy of this licence, visit http://creativecommons.org/licenses/by/4.0/.

\section{References}

1. Schlögl R (2010) The role of chemistry in the energy challenge. Chemsuschem 3:209-222

2. Carmo M, Fritz DL, Mergel J, Stolten D (2013) A comprehensive review on PEM water electrolysis. Int J Hydrog Energy 38:4901-4934
3. Wang W, Wang S, Ma X, Gong J (2011) Recent advances in catalytic hydrogenation of carbon dioxide. Chem Soc Rev 40:3703-3727

4. Bowker $\mathrm{M}$ (2019) Methanol synthesis from $\mathrm{CO}_{2}$ Hydrogenation. ChemCatChem 11:4238-4246

5. Sheldon D (2017) Methanol production-A technical history. Johns Matthey Technol Rev 61:172-182

6. Olah GA (2005) Beyond oil and gas: The methanol economy. Angew Chem Int Ed 44:2636-2639

7. Shen W-J, Jun K-W, Choi H-S, Lee K-W (2000) Thermodynamic investigation of methanol and dimethyl ether synthesis from $\mathrm{CO}_{2}$ Hydrogenation. Korean J Chem Eng 17:210-216

8. Ruiz Esquius J, Bahruji H, Taylor SH, Bowker M, Hutchings G (2020) $\mathrm{CO}_{2}$ hydrogenation to $\mathrm{CH}_{3} \mathrm{OH}$ over PdZn catalysts, with reduced $\mathrm{CH}_{4}$ production. ChemCatChem 12:6024-6032

9. Arcoumanis C, Bae C, Crookes R, Kinoshita E (2008) The potential of di-methyl ether (DME) as an alternative fuel for compression-ignition engines: A review. Fuel 87:1014-1030

10. Xu M, Lunsford JH, Goodman DW, Bhattacharyya A (1997) Synthesis of dimethyl ether (DME) from methanol over solidacid catalysts. Appl Catal Gen 149:289-301

11. Álvarez A, Bansode A, Urakawa A, Bavykina A, Wezendonk T, Makkee M, Gascon J, Kapteijn F (2017) Challenges in the greener production of formates/formic acid, methanol, and DME by heterogeneously catalyzed $\mathrm{CO}_{2}$ hydrogenation processes. Chem Rev 117:9804-9838

12. Spencer MS (1999) The role of zinc oxide in $\mathrm{Cu} / \mathrm{ZnO}$ catalysts for methanol synthesis and the water-gas shift reaction. Top Catal 8:259

13. Twigg MV, Spencer MS (2003) Deactivation of copper metal catalysts for methanol decomposition, methanol steam reforming and methanol synthesis. Top Catal 22:191-203

14. Spencer MS (1987) $\alpha$-Brass formation in copper/zinc oxide catalysts: I. Bulk equilibrium concentrations of zinc under methanol synthesis and water-gas shift reaction conditions. Surf Sci 192:323-328

15. Spencer MS (1987) $\alpha$-brass formation in copper/zinc oxide catalysts: II. Diffusion of zinc in copper and $\alpha$-brass under reaction conditions. Surf Sci 192:329-335

16. Spencer MS (1987) $\alpha$-brass formation in copper/zinc oxide catalysts: III. Surface segregation of zinc in $\alpha$-brass. Surf Sci 192:336-343

17. Burch R, Golunski SE, Spencer MS (1990) The role of copper and zinc oxide in methanol synthesis catalysts. J Chem Soc Faraday Trans 86:2683-2691

18. Aguayo AT, Ereña J, Sierra I, Olazar M, Bilbao J (2005) Deactivation and regeneration of hybrid catalysts in the single-step synthesis of dimethyl ether from syngas and $\mathrm{CO}_{2}$. Int Conf GasFuel 05(106):265-270

19. Naik SP, Ryu T, Bui V, Miller JD, Drinnan NB, Zmierczak W (2011) Synthesis of DME from $\mathrm{CO}_{2} / \mathrm{H}_{2}$ gas mixture. Chem Eng J 167:362-368

20. Frusteri F, Bonura G, Cannilla C, Drago Ferrante G, Aloise A, Catizzone E, Migliori M, Giordano G (2015) Stepwise tuning of metal-oxide and acid sites of CuZnZr-MFI hybrid catalysts for the direct DME synthesis by $\mathrm{CO}_{2}$ hydrogenation. Appl Catal B Environ 176-177:522-531

21. Catizzone E, Bonura G, Migliori M, Frusteri F, Giordano G (2018) $\mathrm{CO}_{2}$ Recycling to dimethyl ether: state-of-the-art and perspectives. Molecules 23(1):1420-3049

22. Munnik P, de Jongh PE, de Jong KP (2015) Recent developments in the synthesis of supported catalysts. Chem Rev 115:6687-6718

23. Li J-L, Inui T (1996) Characterization of precursors of methanol synthesis catalysts, copper/zinc/aluminum oxides, precipitated at different pHs and temperatures. Appl Catal Gen 137:105-117 
24. Li J-L, Inui T (1996) Enhancement in methanol synthesis activity of a copper/zinc/aluminum oxide catalyst by ultrasonic treatment during the course of the preparation procedure. Appl Catal Gen 139:87-96

25. Jingfa D, Qi S, Yulong Z, Songying C, Dong W (1996) A novel process for preparation of a $\mathrm{Cu} / \mathrm{ZnO} / \mathrm{Al}_{2} \mathrm{O}_{3}$ ultrafine catalyst for methanol synthesis from $\mathrm{CO}_{2}+\mathrm{H}_{2}$ : comparison of various preparation methods. Appl Catal Gen 139:75-85

26. Ning W, Shen H, Liu H (2001) Study of the effect of preparation method on $\mathrm{CuO}-\mathrm{ZnO}-\mathrm{Al}_{2} \mathrm{O}_{3}$ catalyst. Appl Catal Gen 211:153-157

27. Forde MM, Kesavan L, Bin Saiman MI, He Q, Dimitratos N, Lopez-Sanchez JA, Jenkins RL, Taylor SH, Kiely CJ, Hutchings GJ (2014) High activity redox catalysts synthesized by chemical vapor impregnation. ACS Nano 8:957-969

28. Forde MM, Armstrong RD, Hammond C, He Q, Jenkins RL, Kondrat SA, Dimitratos N, Lopez-Sanchez JA, Taylor SH, Willock D, Kiely CJ, Hutchings GJ (2013) Partial oxidation of ethane to oxygenates using $\mathrm{Fe}-$ and $\mathrm{Cu}$-containing ZSM-5. J Am Chem Soc 135:11087-11099

29. Bahruji H, Armstrong RD, Ruiz Esquius J, Jones W, Bowker M, Hutchings GJ (2018) Hydrogenation of $\mathrm{CO}_{2}$ to dimethyl ether over brønsted acidic PdZn catalysts. Ind Eng Chem Res 57:6821-6829

30. Bahruji H, Bowker M, Jones W, Hayward J, Ruiz Esquius J, Morgan DJ, Hutchings GJ (2017) PdZn catalysts for $\mathrm{CO}_{2}$ hydrogenation to methanol using chemical vapour impregnation (CVI). Faraday Discuss 197:309-324

31. Sing K (2001) The use of nitrogen adsorption for the characterisation of porous materials. Colloids Surf Physicochem Eng Asp 187-188:3-9

32. Bateni H, Able C (2019) Development of heterogeneous catalysts for dehydration of methanol to dimethyl ether: A review. Catal Ind 11:7-33

33. Jiang S, Hwang J-S, Jin T, Cai T, Cho W, Baek YS, Park SE (2004) Dehydration of methanol to dimethyl ether over ZSM-5 zeolite. Bull Korean Chem Soc 25:185-189

34. Arena F, Dario R, Parmaliana A (1998) A characterization study of the surface acidity of solid catalysts by temperature programmed methods. Appl Catal Gen 170:127-137

35. Karge HG, Vera D (1990) Investigation of the distribution of acidity in zeolites by temperature-programmed desorption of probe molecules. I Dealuminated mordenites J Phys Chem 94:765-772

36. Schröder K-P, Sauer J (1993) Siting of Al and bridging hydroxyl groups in zeolite catalysts. Computer simulations of their structure, vibrational spectra and acidity. In: von Ballmoos R, Higgins JB, Treacy MMJ (eds) Proceedings from the Ninth International Zeolite Conference. Butterworth-Heinemann, Oxford, pp 687-694
37. Brändle M, Sauer J (1998) Acidity differences between inorganic solids induced by their framework structure. A combined quantum mechanics/molecular mechanics ab initio study on zeolites. J Am Chem Soc 120:1556-1570

38. Bonura G, Cordaro M, Spadaro L, Cannilla C, Arena F, Frustaeri $\mathrm{F}$ (2013) Hybrid $\mathrm{Cu}-\mathrm{ZnO}-\mathrm{ZrO}_{2} / \mathrm{H}-\mathrm{ZSM} 5$ system for the direct synthesis of DME by $\mathrm{CO}_{2}$ hydrogenation. Appl Catal B Environ 140-141:16-24

39. Bonura G, Migliori M, Frusteri L, Cannilla C, Catizzone E, Giordano G, Frusteri F (2018) Acidity control of zeolite functionality on activity and stability of hybrid catalysts during DME production via $\mathrm{CO}_{2}$ hydrogenation. J CO2 Util 24:398-406

40. Hwang A, Bhan A (2019) Deactivation of zeolites and zeotypes in methanol-to-hydrocarbons catalysis: Mechanisms and circumvention. Acc Chem Res 52:2647-2656

41. Rownaghi AA, Hedlund J (2011) Methanol to gasoline-range hydrocarbons: influence of nanocrystal size and mesoporosity on catalytic performance and product distribution of ZSM-5. Ind Eng Chem Res 50:11872-11878

42. Chang CD, Chu CT-W, Socha RF (1984) Methanol conversion to olefins over ZSM-5: I. Effect of temperature and zeolite $\mathrm{SiO}_{2} \mathrm{Al}_{2} \mathrm{O}_{3}$. J Catal 86:289-296

43. Chang CD, Lang William H (1977) Process for manufacturing olefins. Mobil Oil Corporation, US4025576A

44. Yarulina I, Chowdhury AD, Meirer F, Weckhuysen BM, Gascon J (2018) Recent trends and fundamental insights in the methanolto-hydrocarbons process. Nat Catal 1:398-411

45. Wang W, Hunger M (2008) Reactivity of surface alkoxy species on acidic zeolite catalysts. Acc Chem Res 41:895-904

46. Ilias S, Bhan A (2013) Mechanism of the catalytic conversion of methanol to hydrocarbons. ACS Catal 3:18-31

47. Ilias S, Bhan A (2012) Tuning the selectivity of methanol-tohydrocarbons conversion on H-ZSM- 5 by co-processing olefin or aromatic compounds. J Catal 290:186-192

48. Dahl IM, Kolboe S (1993) On the reaction mechanism for propene formation in the MTO reaction over SAPO-34. Catal Lett 20:329-336

49. Khare R, Liu Z, Han Y, Bhan A (2017) A mechanistic basis for the effect of aluminum content on ethene selectivity in methanolto-hydrocarbons conversion on HZSM-5. J Catal 348:300-305

Publisher's Note Springer Nature remains neutral with regard to jurisdictional claims in published maps and institutional affiliations. 